\title{
An Epidemic of Almond Witches'-broom in Lebanon: Classification and Phylogenetic Relationships of the Associated Phytoplasma
}

\author{
Yusuf Abou-Jawdah, Armig Karakashian, and Hana Sobh, Faculty of Agricultural and Food Sciences, American \\ University of Beirut, P.O. Box 11-0236, Beirut, Lebanon; and Marta Martini and Ing-Ming Lee, Molecular Plant \\ Pathology Laboratory, Agricultural Research Service, USDA, Beltsville, MD 20705
}

\begin{abstract}
Abou-Jawdah, Y., Karakashian, A., Sobh, H., Martini, M., and Lee, I.-M. 2002. An epidemic of almond witches'-broom in Lebanon: Classification and phylogenetic relationships of the associated phytoplasma. Plant Dis. 86:477-484.

An epidemic of almond witches'-broom has devastated almond production in Lebanon. Thousands of almond trees have died over the past 10 years due to the rapid spread of the disease. The symptoms, which include early flowering, stunted growth, leaf rosetting, dieback, off-season growth, proliferation of slender shoots, and witches'-brooms arising mainly from the main trunk and roots, resemble those caused by phytoplasmal infections. For the detection of the putative causal agent, nested polymerase chain reaction (PCR) was performed using universal primers (P1/P7, $\mathrm{R} 16 \mathrm{mF} 2 / \mathrm{R} 16 \mathrm{mR} 1$, and R16F2n/R16R2) commonly used for the specific diagnosis of plant pathogenic phytoplasmas. Phytoplasmas were readily detected from infected trees with witches'-broom symptoms collected from three major almond growing regions in Lebanon. Restriction fragment length polymorphism (RFLP) analysis of PCR products amplified by the primer pair $\mathrm{R} 16 \mathrm{~F} 2 \mathrm{n} / \mathrm{R} 16 \mathrm{R} 2$ revealed that the phytoplasma associated with infected almonds is similar to, but distinct from, members of the pigeon pea witches'-broom phytoplasma group (16SrIX). A new subgroup, 16SrIX-B, was designated. Sequencing of the amplified products of the phytoplasma 16S rRNA gene indicated that almond witches'-broom (AlmWB) phytoplasma is most closely related to members of the pigeon pea witches'-broom phytoplasma group (with sequence homology ranging from 98.4 to $99.0 \%$ ). Phylogenetic analysis of 16S rDNA sequences from AlmWB phytoplasma and from representative phytoplasmas from GenBank showed that the AlmWB phytoplasma represents a distinct lineage within the pigeon pea witches'-broom subclade. The same phytoplasma appears also to infect peach and nectarine seedlings.
\end{abstract}

Stone fruits are affected by several diseases associated with plant pathogenic phytoplasmas. In Europe, phytoplasmas were reported to cause significant loss of production in apricot (apricot chlorotic leaf roll, ACLR) (29), plum (Japanese plum leptonecrosis, JPL) (14), and peach (28,30). Cross-inoculation experiments (11), DNA sequence analysis, and restriction fragment length polymorphism (RFLP) analysis revealed that most known European stone fruit phytoplasmas are genetically similar (3). Therefore, the name European stone fruit yellows (ESFY) has been proposed (27). A recently revised classification scheme for phytoplasmas, based on RFLP analysis of the 16S rDNA, differentiates phytoplasmas into 14 major phylogenetic groups (26). ESFY phytoplasmas belong to group 16SrX (apple proliferation group), subgroup B. ESFY

Corresponding author: Ing-Ming Lee

E-mail: leeim@ba.ars.usda.gov

Accepted for publication 18 December 2001.

Publication no. D-2002-0304-03R

This article is in the public domain and not copyrightable. It may be freely reprinted with customary crediting of the source. The American Phytopathological Society, 2002.
Seemüller et al. (33). Other members of this group include apple proliferation (AP) and pear decline (PD) phytoplasmas. In North America, peach yellow leaf roll (PYLR) is associated with a phytoplasma related to PD phytoplasma $(22,23,33)$. ESFY phytoplasmas are only distantly related to $\mathrm{X}$-disease phytoplasmas (Xdisease group or $16 \mathrm{SrIII}$ group) that are associated with X-diseases of peach (Xdisease CX or WX) and of chokecherry (X-disease CCX). Other distantly related phytoplasmas that infect stone fruits include cherry molières disease (MOL) from France (5) and cherry lethal yellows (CLY) from China (36), which belongs to $16 \mathrm{SrV}$ (elm yellows group) (26). Almond, another member of the stone fruit family, has been reported to be infected by phytoplasmas in several cases $(14,18,25,27,34)$.

Stone fruits, with almond occupying the largest acreage, represent the major fruit crops grown in Lebanon (13). The area devoted to stone fruit production $(23,000$ ha) ranks first among fruit trees compared with grape at 15,500 ha, citrus at 15,000 ha, and pome fruits at 12,600 ha (13). In the $1980 \mathrm{~s}$ and $1990 \mathrm{~s}$, the area devoted to

almond production in Lebanon increased phytoplasmas were also classified as memcording to the scheme proposed by
Table 1. Detection of phytoplasmas by polymerase chain reaction (PCR) in almond samples collected from different almond growing areas in Lebanon

\begin{tabular}{|c|c|c|c|c|}
\hline Sites & $\begin{array}{l}\text { Presence of } \\
\text { symptoms }^{\mathrm{a}}\end{array}$ & $\begin{array}{l}\text { Number of } \\
\text { samples }\end{array}$ & $\begin{array}{l}\text { Positive by } \\
{\text { direct } \text { PCR }^{\mathrm{b}}}^{\mathrm{b}}\end{array}$ & $\begin{array}{c}\text { Positive by } \\
\text { nested PCR }\end{array}$ \\
\hline Furzol (Bekaa) & No & 2 & 0 & 0 \\
\hline \multirow{2}{*}{ Oussaya $^{\mathrm{d}}$ (Bekaa) } & No & 16 & 0 & 0 \\
\hline & Yes & 5 & 5 & 5 \\
\hline Kefraya (Bekaa) & No & 2 & 0 & 0 \\
\hline Bearzleh (north) & No & 1 & 0 & 0 \\
\hline Adbel (north) & No & 1 & 0 & 0 \\
\hline Jbrayel (north) & No & 1 & 0 & 0 \\
\hline Raskifa $^{\mathrm{e}}$ (north) & Yes & 15 & 4 & 9 \\
\hline \multirow[t]{2}{*}{ 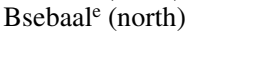 } & No & 1 & 0 & 0 \\
\hline & Yes & 23 & 6 & 18 \\
\hline Bserma (north) & Yes & 1 & 0 & 1 \\
\hline Kfarhazirf $^{f}$ (north) & No & 2 & 0 & 2 \\
\hline Bechmezzine $^{f}$ (north) & No & 3 & 0 & 0 \\
\hline Kfaraka $^{\mathrm{f}}$ (north) & No & 4 & 0 & 1 \\
\hline Batroun (north) & No & 2 & 0 & 0 \\
\hline Rachana (north) & No & 11 & 0 & 0 \\
\hline \multirow[t]{2}{*}{ Tanboureet $^{\mathrm{e}}$ (south) } & No & 3 & 0 & 0 \\
\hline & Yes & 20 & 4 & 14 \\
\hline Broumana $(\mathrm{ML})^{\mathrm{g}}$ & No & 3 & 0 & 0 \\
\hline Total & & 116 & 19 & 50 \\
\hline
\end{tabular}

a Symptoms include early flowering, stunted growth, leaf rosetting, shoot proliferation, and witches'-broom.

${ }^{b}$ Direct PCR with universal primers P1/P7.

${ }^{c}$ Nested PCR with primers P1/P7 followed by primers R16F2n/R16R2.

${ }^{\mathrm{d}}$ Symptoms localized in one patch of the orchard.

${ }^{\text {e }}$ Symptoms widespread in the area. Samples were collected from well-maintained orchards in Raskifa and from either well or not properly maintained orchards in Bsebaal.

${ }^{\mathrm{f}}$ Locations close to infected areas.

g Mount Lebanon. 
Table 2. Detection of phytoplasmas by polymerase chain reaction (PCR) in peach and nectarine samples collected from peach growing areas in Lebanon

\begin{tabular}{lcccc}
\hline Sites & $\begin{array}{c}\text { Presence of } \\
\text { symptoms }\end{array}$ & $\begin{array}{c}\text { Number of } \\
\text { samples }\end{array}$ & $\begin{array}{c}\text { Positive by } \\
\text { direct PCR }\end{array}$ & $\begin{array}{c}\text { Positive by } \\
\text { nested PCR }\end{array}$ \\
\hline Peach & No & 1 & 0 & 0 \\
Furzol (Bekaa) & No & 2 & 0 & 0 \\
Deir El Kamar & No & & & 0 \\
(Mount Lebanon) & No & 2 & 0 & 0 \\
Sir (north) & No & 2 & 0 & 0 \\
Katin (north) & Yes & 2 & 0 & 0 \\
Bedjita (north) & No & 4 & 0 & 0 \\
Hesniyeh(north) & No & 2 & 0 & 0 \\
Ebadieh (north) & No & 1 & 0 & 1 \\
Kferhata (north) & Yes & 1 & 0 & 0 \\
Ain Bakra (north) & & 3 & 0 & 4 \\
Bsebaal (north) & Yes $^{\mathrm{d}}$ & 7 & 4 & 5 \\
Nectarine & & 27 & 4 & \\
Bsebaal (north) & & & & \\
Total & & & & \\
\hline
\end{tabular}

a Direct PCR with universal primers P1/P7.

b Nested PCR with P1/P7 followed by R16F2n/R16R2.

c Leaf roll symptoms.

${ }^{\mathrm{d}}$ Symptoms included proliferation of slender shoots, short internodes and small chlorotic leaves, or light green color and seedling decline.

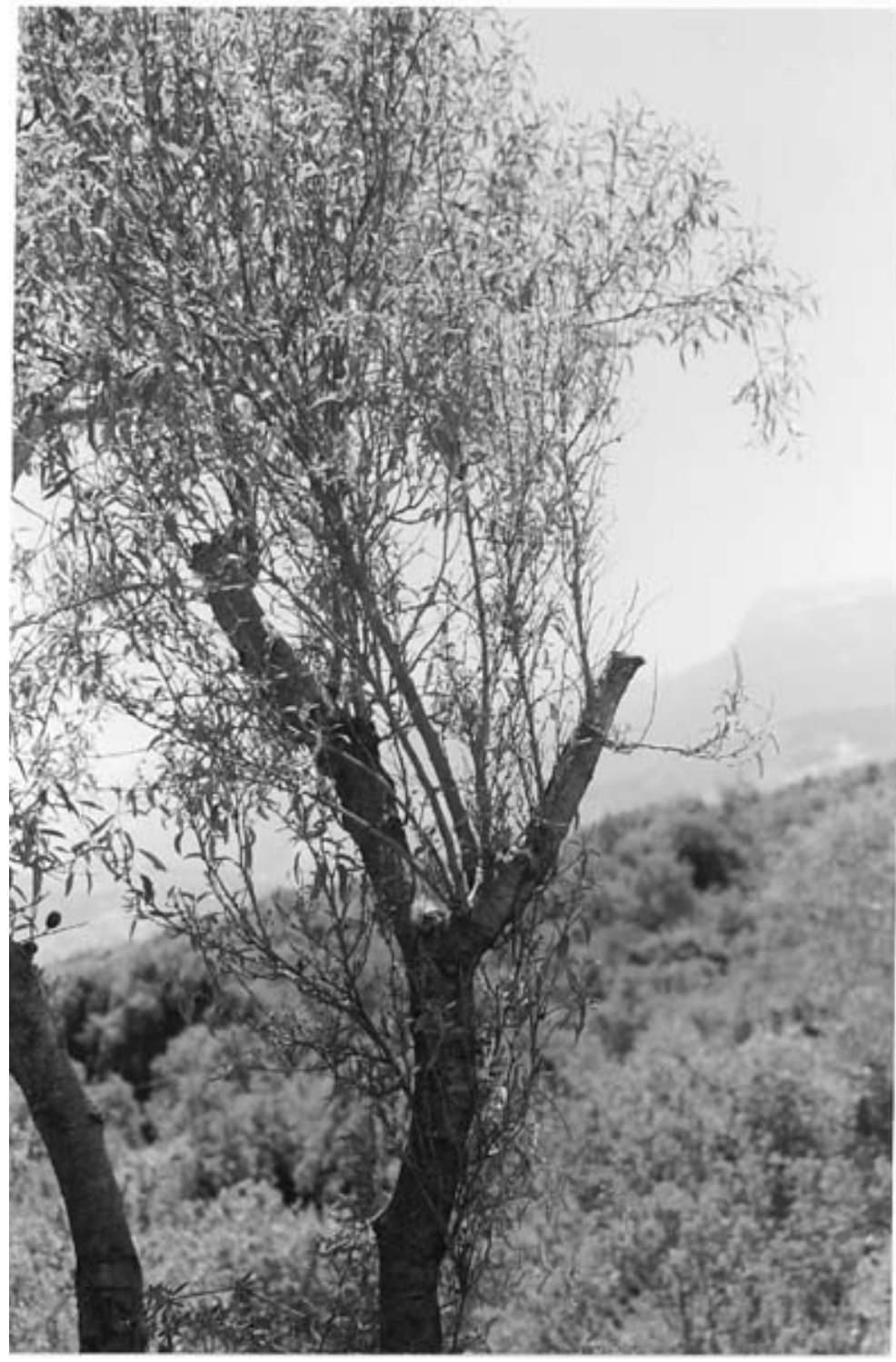

Fig. 1. An almond tree showing extensive shoot proliferation and witches'-broom symptoms. significantly after some growers in the Bekaa Valley preferred growing almond to grape, cherry, and apricot. An unknown disease associated with almond has led to rapid decline of almond trees in three major almond production regions in Lebanon during the last decade. The first epidemic occurred in the south in the early 1990s. A survey conducted in 1998 to 1999 using enzyme-linked immunosorbent assay (ELISA) showed that most declining trees were free from infection by six of the major stone fruit viruses (20). Very large galls induced by Agrobacterium tumefaciens were observed on the roots of a few declining almond trees. These may have accounted for the deaths of many seedlings, but they cannot be the cause of rapid decline of trees over 20 years old. Similar symptoms of almond decline (but without the crown gall) occurred in north Lebanon starting in 1995. The disease spread rapidly, first in the coastal areas to an elevation up to about $500 \mathrm{~m}$, where the majority of almond orchards are located. But a few trees at higher elevations $(1,000 \mathrm{~m})$ also showed the characteristic symptoms. A phytoplasma was suspected due to the presence of witches'-broom symptoms arising from tree trunks.

Recent detection techniques for phytoplasmas include ELISA using monoclonal antibodies $(7,10)$, DNA hybridization $(9,24)$, and polymerase chain reaction (PCR) $(19,30,31)$. In this study, we opted for PCR for three main reasons: sensitivity and rapidity of the test and the availability of universal primers for diagnosis of phytoplasmas. The present paper reports the outbreak of an epidemic of almond witches'-broom disease in several almond growing regions in Lebanon and the molecular identification and phylogenetic relationships of a phytoplasma associated with the disease. A preliminary survey indicated that the same phytoplasma caused diseases in some nectarine and peach seedlings with shoot proliferation symptoms in a field adjacent to an infected almond orchard.

\section{MATERIALS AND METHODS}

Sources of naturally infected plant materials. Surveys were conducted in the major almond growing areas. Field observations showed that almond plants from seedling stage to over 30 years old were infected. Trees showing symptoms suggestive of phytoplasmal infection were sampled. Leaves and, in some cases, other tissues (barks, petals, and fine roots) were collected for total nucleic acid extraction. The samples were weighed and maintained at $4^{\circ} \mathrm{C}$ until processing (normally within 2 days) or stored for a longer time at $-20^{\circ} \mathrm{C}$. In total, 116 samples were collected from different locations ( 23 from south, 68 from north, and 25 from Bekaa) (Table 1). In addition, leaf samples were collected from asymptomatic or symptomatic peach trees 
growing in different areas showing leaf roll symptoms, and from nectarine and peach seedlings with proliferation symptoms grown near an infected almond orchard (Table 2).

Nucleic acid extraction. Leaf midribs were used for nucleic acid extraction from all samples except some from which extraction was also performed using leaf petioles, petals, green bark from proliferating shoots, and fine roots. The small-scale procedure for nucleic acid extraction, described by Zhang et al. (35), was followed with a minor modification of the extraction buffer (CTAB buffer: 2\% CTAB, $1.4 \mathrm{M}$ $\mathrm{NaCl}, 20 \mathrm{mM}$ EDTA, $1 \%$ polyvinylpyrrolidone (PVP), $0.2 \%$ mercaptoethanol, 100 $\mathrm{mM}$ Tris-HCl, $\mathrm{pH} 8.0$ ). About $100 \mathrm{mg}$ of midrib or other tissue types were immersed in liquid nitrogen and ground using a pestle attached to an electrical drill. The nucleic acid pellet was washed with $80 \%$ ethanol, air-dried, suspended in $50 \mu$ of sterile water, and maintained at $-20^{\circ} \mathrm{C}$ until use.

Primers and PCR amplification. Three pairs of universal primers previously de- signed for the detection of phytoplasmas were used in nested PCR. The first PCR run was done either with primer pair $\mathrm{P} 1 / \mathrm{P} 7$ (32), which primes a fragment, approximately $1,800 \mathrm{bp}$, that extends from the $5^{\prime}$ end of the $16 \mathrm{~S}$ rDNA to the $5^{\prime}$ region of the $23 \mathrm{~S}$ rDNA, or with primer pair R16mF2/ R16mR1, which primes a 16S rDNA fragment of approximately 1,435 bp. Nested PCR was performed with primer pair R16F2n/R16R2 (15). Amplifications were performed with an Icycler thermocycler (Bio-Rad Laboratories, Hercules, CA) in $20-\mu \mathrm{l}$ reactions containing $200 \mathrm{mM}$ each of the four dNTPs, $0.5 \mu \mathrm{M}$ of each primer, 2 $\mathrm{mM} \mathrm{MgCl} 2,1 \times$ polymerase buffer, 1 unit Taq (Abgene, Surrey, UK) polymerase and 1 to $2 \mu$ l of sample nucleic acid (about 10 to $20 \mathrm{ng}$ ). Parameters used for 35 cycle PCRs were: denaturation at $94^{\circ} \mathrm{C}$ for $30 \mathrm{~s}$ (2 min for the first cycle), annealing at $50^{\circ} \mathrm{C}$ for $30 \mathrm{~s}$, and extension at $72^{\circ} \mathrm{C}$ for 2 $\min (7 \mathrm{~min}$ for the last cycle). One $\mu \mathrm{l}$ of the diluted $(1: 40)$ PCR products from the first amplification was used as templates for the nested PCR. The amplified products were analyzed by electrophoresis in $1.2 \%$ agarose gel containing $5 \mu \mathrm{g}$ of ethidium bromide per ml.

RFLP analysis of nested PCR amplified 16S rDNA. PCR products amplified using primer pair $\mathrm{P} 1 / \mathrm{P} 7$ or $\mathrm{R} 16 \mathrm{mF} 2 /$ $\mathrm{R} 16 \mathrm{mR} 1$ followed by primer pair R16F2n/ $\mathrm{R} 16 \mathrm{R} 2$ were analyzed by single restriction endonuclease digestion with the following enzymes according to the instructions of the manufacturer: AluI, BfaI, HaeIII, HhaI, HinfI, HpaII, KpnI, RsaI, TaqI, and ThaI (Life Technologies, Gaithersburg, MD), and MseI and Sau3A (New England Biolabs, Beverly, MA). The restriction products were then separated by electrophoresis through a 5\% polyacrylamide gel and stained in ethidium bromide. DNA bands were visualized with a UV transilluminator. Putative restriction site maps of pigeon pea witches'-broom (PPWB, AF248957), Knautia arvensis phyllody (KAP, Y18052), and almond witches'-broom (AlmWB) phytoplasmas were generated by using the DNASTAR program MapDraw option (DNASTAR, Madison, WI).

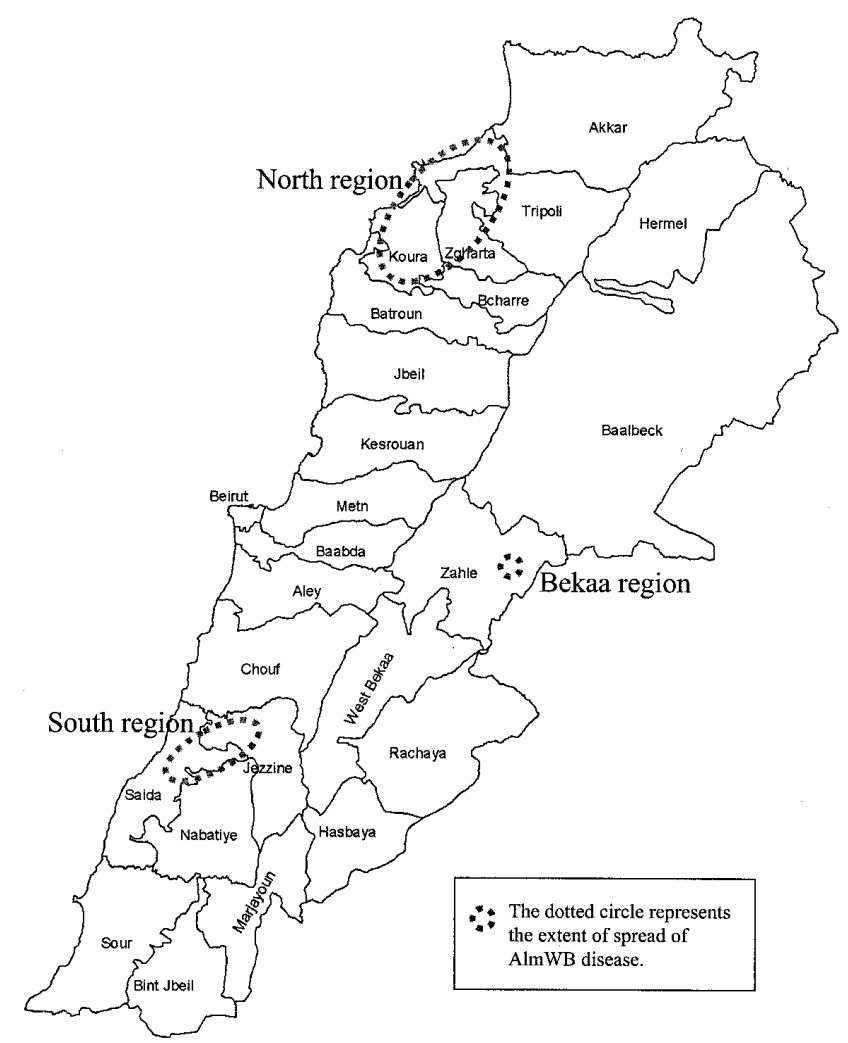

Fig. 2. Map of Lebanon with names of casas indicated, showing the extent of spread of almond witches'-broom disease in three geographical regions (dotted line).

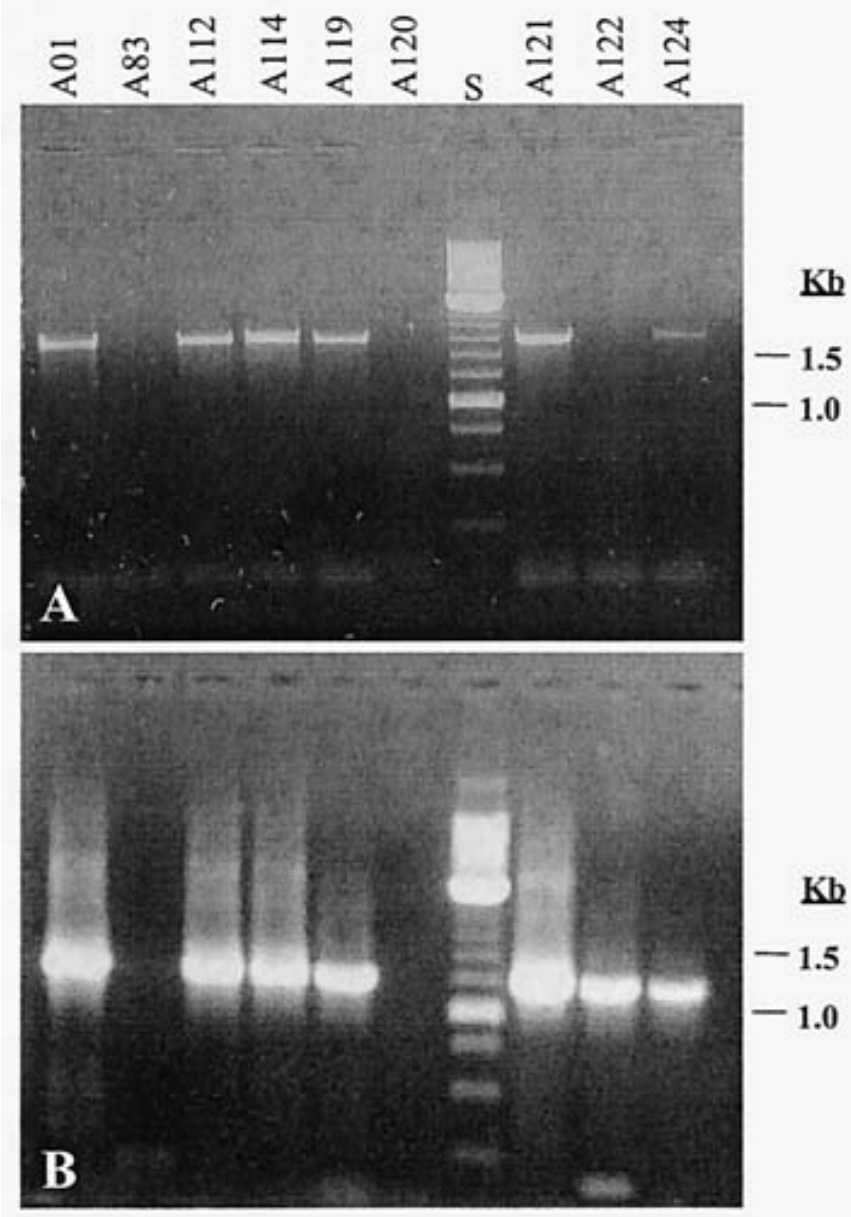

Fig. 3. Direct and nested polymerase chain reaction (PCR) amplifications of phytoplasma 16S rDNA from almond samples suspected of being infected with phytoplasma, collected from different locations. Direct PCR was performed A, using primer pair P1/P7; this was followed by a nested PCR amplification, $\mathbf{B}$, using the primers $\mathrm{R} 16 \mathrm{~F} 2 \mathrm{n} / \mathrm{R} 16 \mathrm{R} 2$. PCR products were separated by electrophoresis through a $1.2 \%$ agarose gel. Lanes 1 and 2 resulted from samples (A01 and A83) collected from Bekaa; 3 and 4 (samples A112, A114) from the south; 5, 6, 8, 9, and 10 (samples A119, A120, A121, A122, A124, respectively) from the north. Lane $\mathrm{S}, 250 \mathrm{bp}$ DNA ladder. 
Phylogenetic analysis. The amplified fragments $(1.8 \mathrm{~kb})$ obtained by PCR using primer pair $\mathrm{P} 1 / \mathrm{P} 7$ were purified using Qiaquick PCR Purification Kit (Qiagen, Valencia, CA) and cloned in Escherichia coli using the TOPO-TA Cloning Kit (Invitrogen, Carlsbad, CA) according to the manufacturer's instructions. P1/P7 PCR amplified products from four almond samples (A121-1, A121-B from north, A114 from south, and A01 from Bekaa region), one peach (P244), and one nectarine (N231) were cloned. Sequencing was performed with an automated DNA sequencer (ABI Prism Model 377) at the Center for Agricultural Biotechnology, University of Maryland, College Park. The nucleotide sequence was aligned with highly homologous sequences in GenBank and EMBL databases using the Gapped BLAST pro-
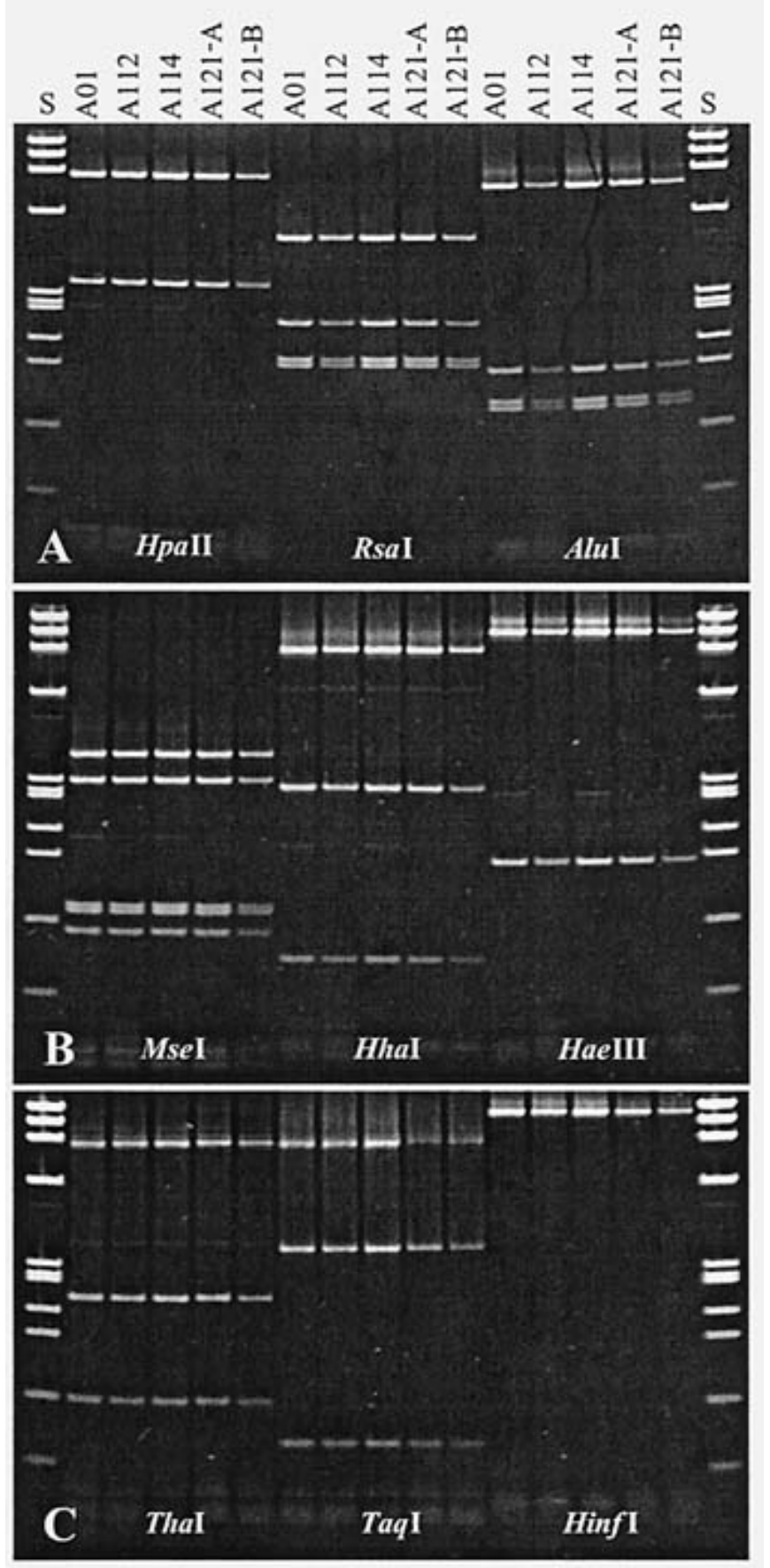

Fig. 4. Restriction fragment length polymorphism (RFLP) analyses of phytoplasma 16S rDNA sequences $(\mathrm{R} 16 \mathrm{~F} 2 \mathrm{n} / \mathrm{R} 16 \mathrm{R} 2$ nested polymerase chain reaction $[\mathrm{PCR}]$ products) amplified from five different almond samples showing witches'-broom symptoms. The samples were collected from different regions: Bekaa (A01), South (A112, A114), and North (A121-A, A121-B). DNA products were digested with A, HpaII, RsaI, and $A l u \mathrm{I}$; B, MseI, HhaI, and HaeIII; and C, ThaI, TaqI, and Hinfl, and separated by electrophoresis through a 5\% polyacrylamide gel. Lane S, $\Phi$ X174 RFI DNA HaeIII digest, fragment sizes (bp) from top to bottom: 1,353, 1,078, 872, 603, 310, 281, 271, 234, 194, 118, 72. The first PCR was performed with P1/P7 primer pair.

gram (4) and performing gapped and ungapped analyses. Partial sequences $(1.5 \mathrm{~kb})$ of $16 \mathrm{~S}$ rDNA from AlmWB phytoplasma and representative phytoplasma strains available in GenBank were aligned separately by using CLUSTAL, version 5 , and DNASTAR's Laser Gene software (DNASTAR). Cladistic analyses were performed with PAUP (phylogenetic analysis using parsimony) version 4.0 written by D. L. Swofford (University of Illinois) on a Power Mac G4. Uninformative characters were excluded from analyses. A phylogenetic tree was constructed by a heuristic search via random stepwise addition implementing the tree bisection and reconnection branch-swapping algorithm to find the optimal tree(s). Acholeplasma laidlawii was selected as the out-group to root the tree. The analysis was replicated 1,000 times. Bootstrapping was performed to estimate the stability and support for the inferred clades. The cloned nucleotide sequences were deposited as accessions AF390136 (AlmWB1 = A01), AF390137 $(\mathrm{AlmWB} 2=\mathrm{A} 121-\mathrm{A}), \mathrm{AF} 455038$ (AlmWB3 = A121-B), AF455039 (AlmWB4 = A114), AF455040 (AlmWB-P1 = P244), and AF455041 (AlmWB-N1 = N231).

Survey and symptoms. During the survey, no almond trees showing yellowing and leaf roll symptoms were observed. However, in three regions (Bekaa, north, and south), declining almond trees were observed. The most characteristic symptom found was the proliferation of shoots at several points on the main trunk with an appearance of witches'-broom (Fig. 1). Hence, almond witches'-broom (AlmWB) was adopted as the disease name. As the disease advanced, witches'-brooms emerged on many scaffold branches. Discussion with farmers indicated that the first symptom observed was an early flowering (20 to 30 days earlier than normal), and sometimes witches'-brooms appeared on the main trunk. In the second year, the lower branches showed extensive proliferation with smaller leaves, light green in color, and shoots became stunted with short internodes (rosetting). The yield of fruits on infected almond branches was greatly reduced. The fruits produced were small, dark in color, with shriveled seeds. The trees declined rapidly and died within 3 to 4 years after the initial appearance of symptoms. All cultivated varieties seemed equally susceptible, although some variation in symptoms occurred. Many trees showed stunted growth with short internodes and small leaves; others showed proliferation of several lateral individual slender branches, mostly with an upright growth but without witches'-broom. Even though wild almond (Prunus orientalis) also gets severely infected, a delay in the appearance of symptoms was often observed. During the year 2000, off-season growth started in late October and flowering of infected trees started in mid-November. 
The earliest report of this disease was from South Lebanon. Farmers dated it back to the early 1990 s and claimed that over six thousand almond trees died in several villages located in that region. In North Lebanon (Caza of Zghorta), the introduction of the disease was first recorded as recently as 1995 . Since that time, it has spread very rapidly to cover the entire region from the coastal areas to an elevation of $500 \mathrm{~m}$ where the majority of almond orchards are located, but symptoms also were observed at higher elevations $(1,000 \mathrm{~m})$. The disease then spread to neighboring cazas of Koura and Tripoli (Fig. 2). Most almond trees in this region have died or are dying (over 65,000 trees). So far, no symptoms have been observed in the plain of Akkar, north of Tripoli, one of the major almond production areas. In the third region (in the Bekaa Valley, the major stone fruit growing area), the disease seems to be restricted. Only a group of a few almond trees in one orchard was infected; but the disease did not seem to be spreading to adjacent cherry trees in the same region. However, in the north region in a field and a nursery located near an infected almond orchard, the same phytoplasma appeared to be responsible for diseases in peach and in nectarine seedlings ( 1 to 5 years old), with symptoms suggestive of phytoplasma infection (Table 2).

PCR amplification. Fifty-seven percent of leaf samples collected from symptomatic almond trees from orchards located in the Bekaa (Oussaya), in the south (Tamboureet), and in the north (Raskifa, Bsebaal, Bserma) gave positive results in PCR tests. The additional tests performed in a few symptomatic trees using bark, petals, and fine roots gave positive results consistent with those obtained with leaf tissues. DNA fragments of expected sizes were amplified in extracts prepared from infected trees but not from asymptomatic trees collected from most noninfected areas (data not shown). The approximate sizes of amplified products were 1,800 bp with primers $\mathrm{P} 1 / \mathrm{P} 7,1,435$ bp with primers $\mathrm{R} 16 \mathrm{mF} 2 / \mathrm{R} 16 \mathrm{mR} 1$, and 1,200 bp with primers $\mathrm{R} 16 \mathrm{~F} 2 \mathrm{n} / \mathrm{R} 16 \mathrm{R} 2$. In some cases, nested PCR (with primers P1/P7 or $\mathrm{R} 16 \mathrm{mF} 2 / \mathrm{R} 16 \mathrm{R} 1$ followed by a second run of PCR using primers R16F2n/R16R2) was needed to produce detectable PCR products (Table 1, Fig. 3). Four samples from nectarine seedlings and one sample from peach seedlings showing proliferation tested positive (Table 2). These symptomatic samples were collected from the same area (Bsebaal) in which almond trees were heavily infected (Tables 1 and 2). No positive tests were obtained from asymptomatic peach trees or from trees showing leaf roll symptoms.

Classification of almond witches'broom phytoplasma. The almond witches'-broom (AlmWB) phytoplasma $16 \mathrm{~S}$ rDNA sequences $(1.2 \mathrm{~kb})$ amplified by nested PCR, using the second primer pair $\mathrm{R} 16 \mathrm{~F} 2 \mathrm{n} / \mathrm{R} 16 \mathrm{R} 2$, were subjected to RFLP analysis. Collective RFLP patterns of five AlmWB 16S rDNA sequences, representatives of Bekaa (A01), south (A112, A114), and north (A121-A, A121-B), based on analyses with 12 restriction enzymes were identical and were most similar to those previously published for $16 \mathrm{~S}$ rDNAs from members of the pigeon pea witches'-broom (PPWB) phytoplasma group $(16,21,26)$. The RFLP patterns of AlmWB phytoplasma strains resolved by single digestion with MseI, HpaII, and ThaI (Fig. 4), and with BfaI, KpnI, and Sau3A (data not shown), were identical to those of PPWB phytoplasma. But the patterns resolved by digestions with the other six enzymes (RsaI, AluI, HhaI, HaeIII, TaqI, and HinfI) were distinct from those of PPWB phytoplasma (Fig. 4). RFLP analysis (with eight restriction enzymes) of phytoplasmas amplified from symptomatic peach (P244) and nectarine (N231) samples and a reference PPWB phytoplasma strain revealed that phytoplasma strains P244 and N231 were indistinguishable from AlmWB phytoplasma (A112) and distinct from PPWB phytoplasma (Fig. 5). The close relatedness among almond, peach, and nectarine strains was confirmed by analysis of cloned $16 \mathrm{~S}$ rDNA sequences. The sequence homology among AlmWB phytoplasma strains from almond collected in three different geographical regions, peach, and nectarine strains ranged from 99.6 to $99.9 \%$. The sequence variations were random.

Maps of putative restriction sites of the latter six enzymes were in agreement with the patterns obtained by enzymatic analysis on AlmWB and PPWB phytoplasma strains (Fig. 6). The sequence variation between the two strains involved at least eight different restriction sites in the portion of $16 \mathrm{~S}$ rDNA amplified by R16F2n/R16R2 primer pair. Between AlmWB and Knautia arvenis phyllody (KAP) phytoplasmas, the sequence variation is smaller, involving only four different restriction sites (Fig. 6).

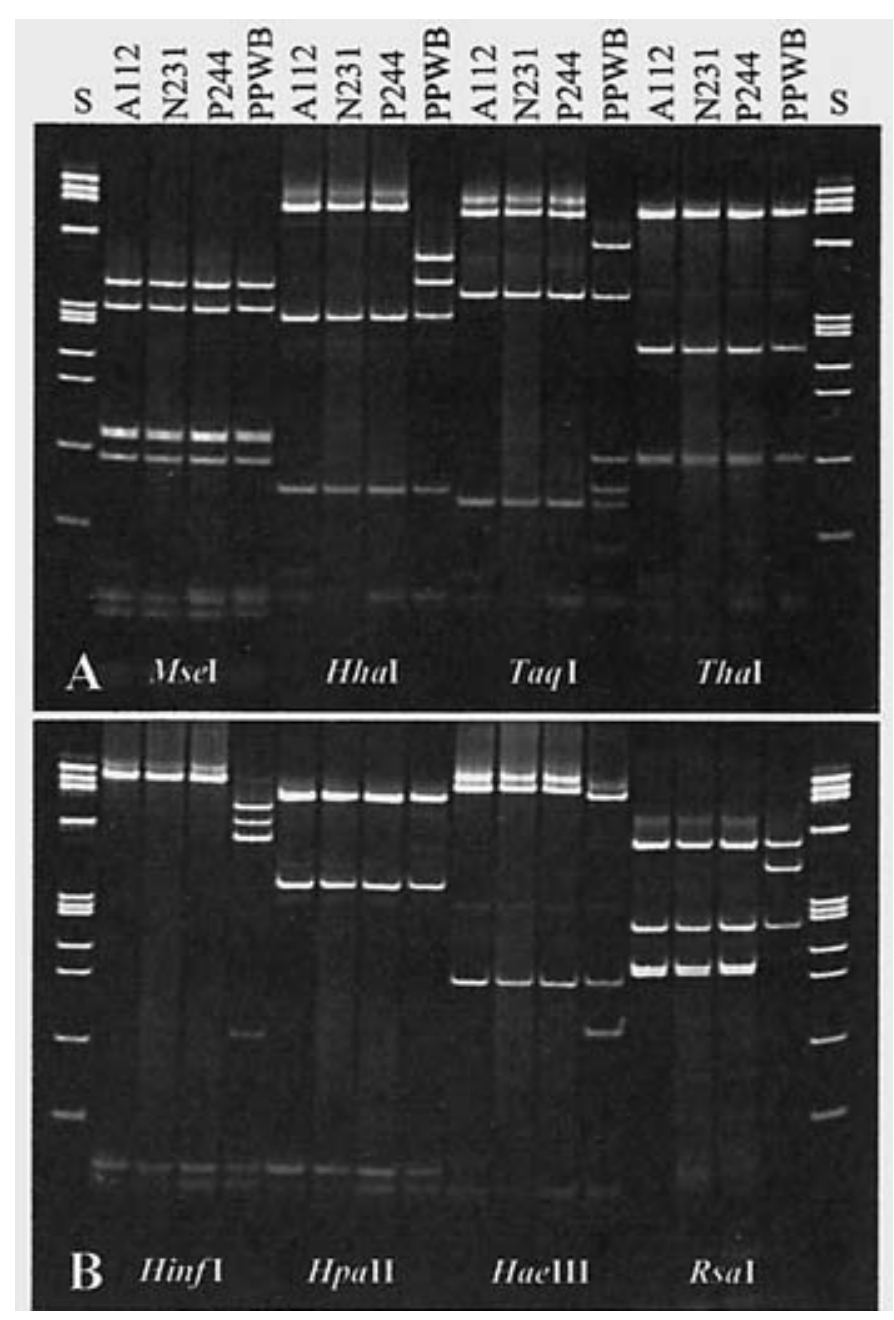

Fig. 5. Restriction fragment length polymorphism (RFLP) analyses of phytoplasma 16S rDNA sequences (R16F2n/R16R2-nested polymerase chain reaction [PCR] products) amplified from almond (A112), peach (P244), nectarine (N231), and a reference phytoplasma strain pigeon pea witches'broom (PPWB). DNA products were digested with A, MseI, HhaI, TaqI, and ThaI; and B, HinfI, HpaII, HaeIII, and RsaI, and separated by electrophoresis through a 5\% polyacrylamide gel. Lane S, ФX174 RFI DNA HaeIII digest, fragment sizes (bp) from top to bottom: 1,353, 1,078, 872, 603, 310, 281, 271, 234, 194, 118, 72. The first PCR was performed with P1/P7 primer pair. 
Based on the RFLP patterns, the new AlmWB phytoplasma was designated a new subgroup 16SrIX-B in the pigeon pea witches'-broom group (16SrIX). KAP phytoplasma could represent another new subgroup, provided that the putative restriction sites can be confirmed by RFLP analysis.

Phylogenetic analysis. BLAST searches were done on regions of the $16 \mathrm{~S}$ rRNA gene (about $1.5 \mathrm{kbp}$ ). Results showed that the AlmWB phytoplasma was most closely related to members of pigeon pea witches'broom phytoplasma group: pigeon pea witches'-broom phytoplasma (accession AF248957) (with 98.4\% identity), Picris echioides yellows (accession Y16389) (with $98.7 \%$ identity), Knautia arvensis phyllody (accession Y18052) (with 99.0\% identity), and Vigna little leaf phytoplasma (accession Y15866) (with 96.5\% identity). However, it was distantly related to the other reported phytoplasmas infecting stone fruits such as peach X-disease, peach yellow leaf roll, and European stone fruit yellows (accession X68374) (less than $87 \%$ identity). Phylogenetic analysis of near-full-length 16S rRNA gene sequences from 62 representative phytoplasma strains and three Acholeplasma species yielded 624 equally parsimonious trees. All the trees resolved similar major phylogenetic groups or subclades identified in previous studies $(26,33)$. A representative tree that most resembled the consensus tree was shown in Figure 7, indicating that AlmWB phytoplasma represents a distinct lineage within the pigeon pea witches'-broom subclade.

\section{DISCUSSION}

In this study, we have done an extensive survey on the spread of almond witches'broom in three major almond production areas in Lebanon (Fig. 2). Recently, Choueiri et al. (8) reported the presence of almond witches'-broom only on a few trees in the Bekaa region. Our results indicated that almond witches'-broom has spread into all three regions (Bekaa, north, and south regions). PCR tests revealed the presence of phytoplasmas in all almond trees with the witches'-broom symptom (100\% correlation) and in most trees where stunting, rosetting, and dieback were the main symptoms. Overall, 57\% symptomatic samples tested positive for phytoplasma. We have found the detection sensitivity could be further improved by using the commercial kit Phytopure (Amersham Pharmacia, England) for DNA extraction.

RFLP and phylogenetic analyses of PCR-amplified 16S rDNA sequences showed that almond witches'-broom (AlmWB) in all three major almondgrowing regions is caused by a new phytoplasma, consistent with the report by Choueiri et al. (8) that a phytoplasma related to PPWB phytoplasma was associated with almond witches'-broom disease. Based on RFLP analysis of $16 \mathrm{~S}$ rDNA, the AlmWB phytoplasma was designated a new subgroup 16SrIX-B within PPWB phytoplasma group (16SrIX). AlmWB phytoplasma is only distantly related to the other reported phytoplasmas that infect stone fruit trees: ESFY and PYLR (belonging to members of $16 \mathrm{SrX}$ group), $\mathrm{X}$ -
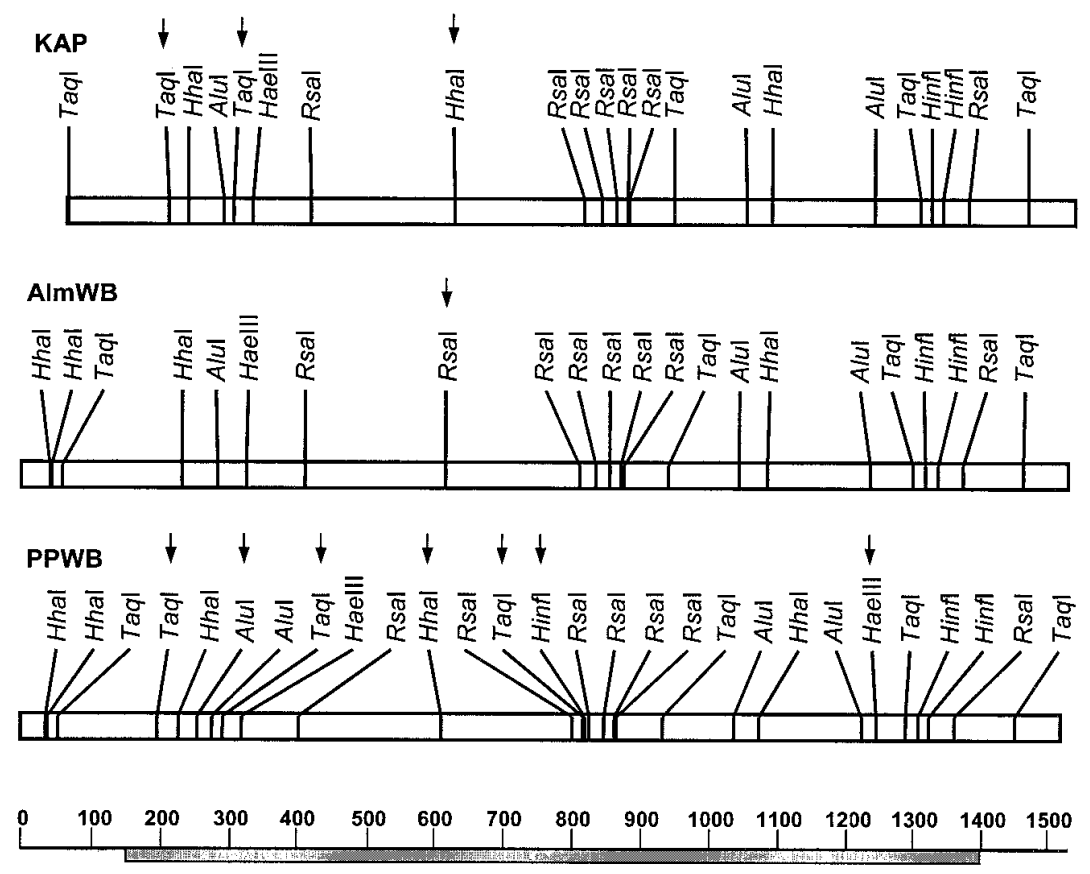

Fig. 6. Maps of putative restriction sites in the nucleotide sequence of 16S rRNA from Knautia arvensis phyllody (KAP), almond witches'-broom (AlmWB) and pigeon pea witches'-broom (PPWB) phytoplasmas. The solid bar on the scale represents the region amplified by primers R16F2n/R16R2. Arrows indicate the sites that are different between AlmWB phytoplasma and each of the two reference phytoplasma strains KAP (Y18052) and PPWB (AF248957).

disease (16SrIII group), and CLY (16SrV group). The finding underscores the genetic diversity of phytoplasma strains that infect stone fruits. The diversity seems to correlate with the geographical distributions of the causal phytoplasmas.

The ESFY and other stone fruit phytoplasmas have been shown to infect apricot, peach, plum, almond, and cherry $(11,12,17,22,25,26)$. These phytoplasmas have caused extensive damage in the production of peach, apricot, and plum in Europe and elsewhere $(5,14,28,29)$. But the disease incidence in almond caused by these phytoplasmas is relatively limited $(14,18,25,34)$. Our study has revealed that a lethal almond disease widespread in Lebanon is attributed to a new phytoplasma that has never been described to be associated with stone fruits grown elsewhere. As ESFY phytoplasma in Europe is involved in several stone fruit yellows diseases, in Lebanon AlmWB phytoplasma appears to also attack peach and nectarine seedlings in areas where almond witches'broom is prevailing.

The rapid spread of the disease that affected young and old trees in both wellmanaged and completely neglected orchards (not plowed or pruned) suggested the involvement of an efficient aerial vector. However, during our survey, we were not able to find leafhoppers or psyllids on almond trees except for Asymmetrasca (Empoasca) sp. in one almond orchard in the south and on other stone fruit seedlings in nurseries in several regions. However, the majority of leafhoppers in this genus do not feed on phloem tissue and were not reported as vectors of phytoplasma. It is quite possible that the vector of almond witches'-broom feeds mainly on weeds and passes only transiently on the lower branches of almond trees. Therefore, it would be difficult to find the vector on almond trees. In Europe, the vector of ESFY was unknown until 1998, when Carraro et al. (6) reported that the plum tree psyllid Cacopsylla pruni was identified as the vector of this phytoplasma. But the psyllid may not likely be a vector candidate for AlmWB phytoplasma that is only distantly related to ESFY and related phytoplasmas (members of apple proliferation group or $16 \mathrm{SrX}$ ). In Lebanon, over 150 species of leafhoppers were identified, and among them at least 10 species were reported as phytoplasma vectors in the literature $(1,2)$. At the present time, we are attempting to trap different leafhopper species found in weeds or crops growing in the orchards and their vicinity.

Almond is an important nut crop grown worldwide; among major almond production countries are the United States (California), southern European countries, and central Asia. AlmWB phytoplasma poses a great threat to almond production due to rapid decline of affected almond trees, to its ability to rapidly spread by a yet un- 


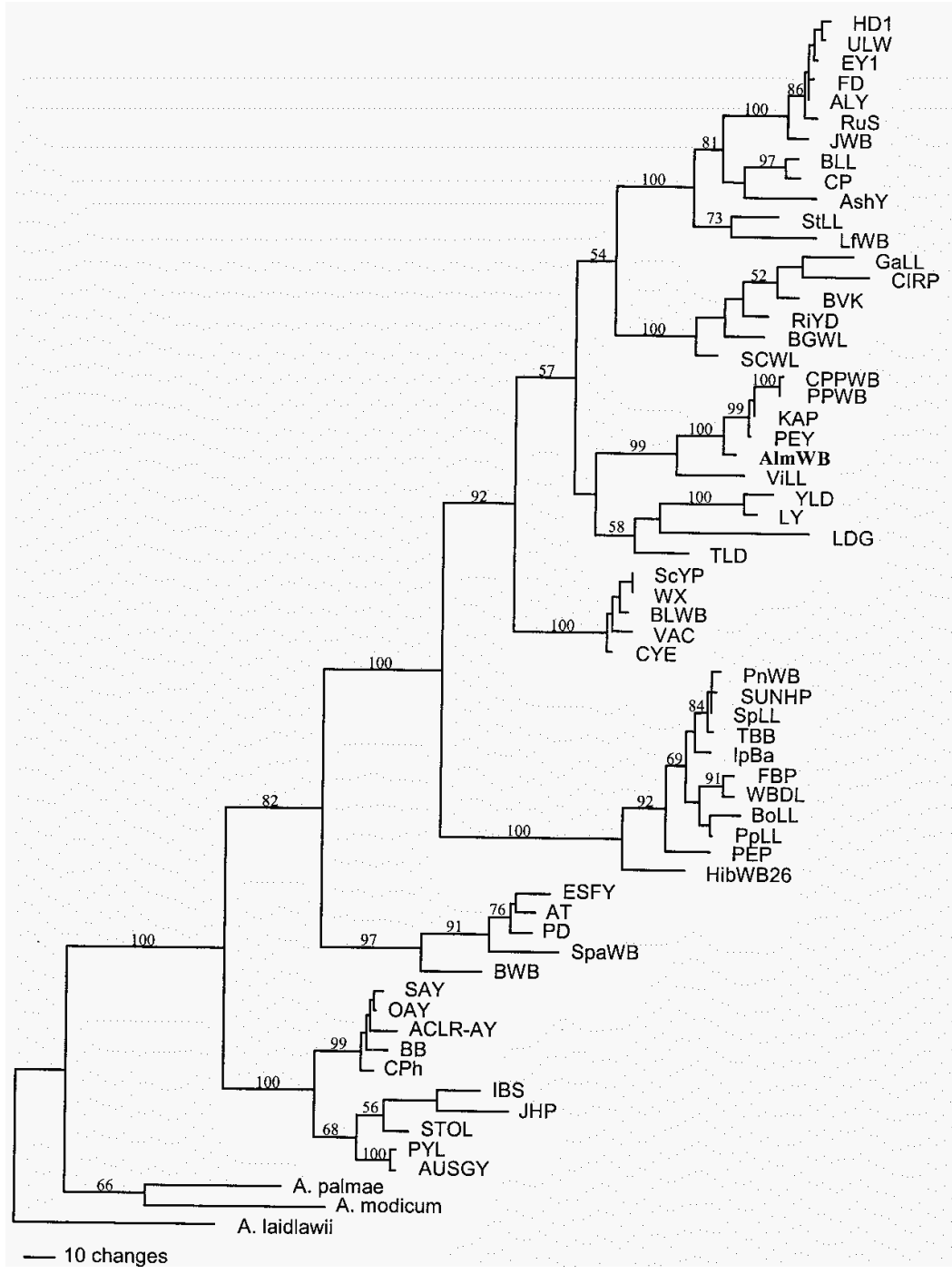

Fig. 7. Phylogenetic tree constructed by parsimony analysis of near-full-length $16 \mathrm{~S}$ rDNA sequences from 62 phytoplasmas and three Acholeplasma spp., employing A. laidlawii as the outgroup. Branch lengths are proportional to number of inferred character state transformations. Bootstrap values (measures of support for inferred subclade) are shown on branches. Phytoplasma strain abbreviations and sequence accession numbers: HD1, hemp dogbane phytoplasma (AF122912); ULW, elm witches'broom/France (X68376); EY1, elm yellows/America (AF189214); FD, Flavescence dorée (X76560); ALY, alder yellows (Y16387); RuS, rubus stunt (Y16395); JWB, jujube witches'-broom (AF305240); BLL, brinjal little leaf (X83431); CP, clover proliferation (L33761); AshY, ash yellows ("Candidatus Phytoplasma fraxini”) (AF189215); StLL, stylosanthes little leaf (Y17055); LfWB, loofah witches'broom (AF248956); GaLL, phytoplasma strain GaLL/Australia (Y15865); CIRP, cirsium phyllody (X83438); BVK, from leafhopper Psammotettix cephalotes (X76429); RiYD, rice yellow dwarf (D12581); BGWL, Bermuda grass white leaf (Y16388); SCWL, sugarcane white leaf (X76432); CPPWB, Chinese pigeon pea witches'-broom (AF028813); PPWB, pigeon pea witches'-broom (AF248957); KAP, Knautia arvensis phyllody (Y18052); PEY, Picris echioides yellows (Y16389); AlmWB, almond witches'-broom (AF390136); ViLL, vigna little leaf (AJ289195); YLD, Yucatan coconut lethal decline (U18753); LY, coconut lethal yellowing (U18747); LDG, coconut lethal yellowing/Ghanaian Cape; TLD, Tanzanian lethal decline of coconut (X80117); ScYP, sugarcane yellows phytoplasma (AF056095); WX, western X disease (U54992); BLWB, black locust witches'-broom (AF244363); VAC, vaccinium witches'-broom (X76430); CYE, clover yellow edge (AF175304); PnWB, peanut witches'-broom (L33765); SUNHP, sunn hemp witches'-broom (X76433); SpLL, sweet potato little leaf (AJ289193); TBB, Australian tomato big bud ("Candidatus Phytoplasma australasia") (Y08173); IpBa, Ipomea batatis (Y90591); FBP, faba bean phyllody (X83432); WBDL, witches'-broom of lime ("Candidatus Phytoplasma aurantifolia") (U15442); BoLL, phytoplasma strain BoLL/Australia (Y15863); PpLL, pigeon pea little leaf (AJ289191); PEP, Picris echioides phyllody (Y16393); HibWB26, hibiscus witches'-broom ("Candidatus Phytoplasma brasiliense") (AF147708); ESFY, European stone fruit yellows (X68374); AT, apple proliferation (X68375); PD, pear decline/Germany (X76425); SpaWB, spartium witches'-broom (X92869); BWB, buckthorn witches'-broom (AF244363); SAY, western severe aster yellows (M86340); OAY, Oenothera aster yellows (M30790); ACLR-AY, aster yellows from apricot (X68338); BB, tomato big bud/Arkansas (L33760); CPh, clover phyllody (L33762); IBS, Italian bindweed stolbur (Y16391); JHP, Japanese hydrangea phyllody ("Candidatus Phytoplasma japonicum") (AB010425); STOL, stolbur of pepper (X76427); PYL, phormium yellow leaf (U43569); AUSGY, Australian grapevine yellows (“Candidatus Phytoplasma australiense”); Acholeplasma palmae (L33734); A. modicum (M23933); A. laidlawii (M23932). known vector, to its high pathogenicity to young and old trees, and to its adaptation to several microclimates, from the coastal region up to an elevation of about $1,000 \mathrm{~m}$. Furthermore, we are now continuing to investigate the extent of cross-infection by AlmWB phytoplasma to other stone fruits and the damage that it may cause. Pest risk analysis shows that the potential economic impact of almond witches'-broom would be very high in the major almond producing countries if AlmWB phytoplasma and its vector are introduced. It is recommended that national, regional, and international action be taken to eradicate or prevent the further spread of this epidemic disease. However, for a successful eradication, it is important to identify the alternative hosts, the vector, and the mode of transmission. Our results call for a more strict certification and quarantine measures on the movement of stone fruit germ plasm. The diagnostic techniques developed for phytoplasma detection should be standardized and used routinely in certification of stone fruits.

\section{ACKNOWLEDGMENTS}

This work was partially supported by a research fellowship from the UNESCO Biotechnology Educational and Training Center for Palestinian Territory and Arab Countries, at Bethlehem, and by the University Research Board, AUB, Lebanon. Part of this work was performed by Marta Martini during her training at MPPL as Ph.D. candidate at the University of Udine, Italy. We thank Rachel Dane for excellent technical assistance.

\section{LITERATURE CITED}

1. Abdul-Nour, H. 1985. Cicadellidae of Lebanon: Records and biological notes. Marburger Ent. Publ. 1(10): 169-190.

2. Abdul-Nour, H. 1987. Cicadellidae of Lebanon: New facts and ideas (Homopt. Auch.). Proc. 2nd Int. Congr. Rhynchota Balkan, Mikrolimni, Greece. 1986:15-16.

3. Ahrens, U., Lorenz, K.-H., and Seemüller, E. 1993. Genetic diversity among mycoplasmalike organisms associated with stone fruit diseases. Mol. Plant-Microbe Interact. 6:686-691.

4. Altschul, S. F., Madden, T. L., Schäffer, A. A., Zhang, J., Zhang, Z., Miller, W., and Lipman, D. J. 1997. Gapped BLAST and PSI-BLAST: A new generation of protein database search programs. Nucleic Acids Res. 25:3389-3402.

5. Bernhard, R., Marénaud, C., Eymet, J., Séchet, J., Fos, A., and Moutous, G. 1977. Une maladie complexe de certains Prunus: le dépérissement de Molières. Compte Rendus Academie Agricole France. pp. 178-189.

6. Carraro, L., Osler, R., Loi, N., Ermacora, P., and Refatti, E. 1998. Transmission of European stone fruit yellows phytoplasma by $\mathrm{Ca}$ copsilla pruni. J. Plant Pathol. 80:233-239.

7. Chen, K. H., Credi, R. C., Loi, N., Maixner, M., and Chen, T.-A. 1994. Identification and grouping of mycoplasmalike organisms associated with grapevine yellows and clover phyllody diseases based on immunological and molecular analyses. Appl. Environ. Microbiol. 60:1905-1913.

8. Choueiri, E., Jreijiri, F., Issa, S., Verdin, E., Bové, J., and Garnier, M. 2001. First report of a phytoplasma disease of almond (Prunus amygdalus) in Lebanon. Plant Dis. 85:802.

9. Daire, X., Boudon-Padieu, E., Berville, A., Schneider, B., and Caudwell, A. 1992. Cloned DNA probes for detection of grapevine fla- 
vescence dorée mycoplasma-like organism (MLO). Ann. Appl. Biol. 121:95-103.

10. Davies, D. L., and Clark, M. F. 1992. Production and characterization of polyclonal and monoclonal antibodies against peach yellow leafroll MLO-associated antigens. Acta Hortic. 309:275-284.

11. Dosba, F. 1992. Les maladies à mycoplasmes. Le point sur les recherches. Arboric. Fruitière 454:24-28.

12. Dosba, F., Lansac, M., Mazy, K., Garnier, M., and Eyquard, J. P. 1990. Incidence of different diseases associated with mycoplasmalike organisms in different species of Prunus. Acta Hortic. 283:311-320.

13. FAO 2000. Resultats globaux du recensement agricole. Ministere de l'Agriculture. Republique Libanaise. p. 122

14. Giunchedi, L., Poggi-Pollini, C., and Credi, R. 1983. Susceptibility of stone fruit trees to the Japanese plum-tree decline causal agent. Acta Hortic. 130:285-290.

15. Gundersen, D. E., and Lee, I.-M. 1996. Ultrasensitive detection of phytoplasmas by nested-PCR assays using two universal primer pairs. Phytopathol. Mediterr. 35:144-151.

16. Harrison, N. A., Tsai, J. H., Bourne, C. M., and Richardson, P. A. 1991. Molecular cloning and detection of chromosomal and extrachromosomal DNA of mycoplasmalike organisms associated with witches'-broom disease of pigeon pea in Florida. Mol. PlantMicrobe Interact. 1:303-310.

17. Jarausch, W., Lansac, M., and Dosba, F. 1999. Seasonal colonization pattern of European stone fruit yellows phytoplasmas in different Prunus species detected by specific PCR. J. Phytopathol. 147:47-54.

18. Jarausch, W., Lansac, M., Saillard, C., Broquaire, J. M., and Dosba, F. 1998. PCR assay for specific detection of European stone fruit yellows phytoplasmas and its use for epidemiological studies in France. Eur. J. Plant Pathol. 104:17-27.

19. Jarausch, W., Saillard, C., Dosba, F., and
Bové, J. M. 1994. Differentiation of mycoplasmalike organisms (MLOs) in European fruit trees by PCR using specific primers derived from the sequence of a chromosomal fragment of the apple proliferation MLO. Appl. Environ. Microbiol. 60:2916-2923.

20. Kannaan-Atallah, Z. H., Abou-Jawdah, Y., and Saad, A. 2000. Virus diseases infecting almond germplasm in Lebanon. Phytopathol. Mediterr. 39:417-422.

21. Kenyon, L., Harrison, N. A., Ashburner, G. R., Boa, E. R., and Richardson, P. A. 1998. Detection of a pigeon pea witches'-broomrelated phytoplasma in trees of Gliricidia sepium affected by little-leaf disease in Central America. Plant Pathol. 47:671-680.

22. Kirkpatrick, B. C. 1991. Mycoplasma-like organisms--Plant and invertebrate pathogens. Pages 4050-4067 in: The Prokaryote. A. Balows, H. G. Trüper, M. Dworkin, W. Harder, and K. H. Schleifer, eds. Springer-Verlag, New York.

23. Kison, H., Kirkpatrick, B. C., and Seemüller, E. 1997. Genetic comparison of peach yellow leaf roll agent with European fruit tree phytoplasmas of apple proliferation group. Plant Pathol. 46:538-544.

24. Ko, H. C., and Lin, C. P. 1994. Development and application of cloned DNA probes for a mycoplasmalike organism associated with sweetpotato witches'-broom. Phytopathology 84:468-473.

25. Lederer, M., and Seemüller, E. 1992. Demonstration of mycoplasmas in Prunus species in Germany. J. Phytopathol. 134:89-96.

26. Lee, I.-M., Gundersen-Rindal, D. E., Davis, R. E., and Bartoszyk, I. M. 1998. Revised classification scheme of phytoplasmas based on RFLP analyses of 16S rRNA and ribosomal protein gene sequences. Int. J. Syst. Bacteriol. 48:1153-1169.

27. Lorenz, K.-H., Dosba, F., Poggi-Pollini, C., Llacer, G., and Seemüller, E. 1994. Phytoplasma diseases on Prunus species in Europe are caused by genetically similar organisms. Z.
Pflanzenkrankh. Pflanzenschutz 101:567-575.

28. Marcone, C., Ragozzino, A., and Seemüller, E. 1996. European stone fruit yellows phytoplasma as the cause of peach vein enlargement and other yellows and decline diseases of stone fruits in Southern Italy. J. Phytopathol. 144:559-564.

29. Morvan, G. 1977. Apricot chlorotic leaf roll. EPPO Bull. 7:37-50.

30. Poggi Pollini, C., Giunchedi, L., and Gambin, E. 1993. Presence of mycoplasma-like organisms in peach trees in Northern-Central Italy. Phytopathol. Mediterr. 32:188-192.

31. Schaff, D. A., Lee, I.-M., and Davis, R. E. 1992. Sensitive detection and identification of mycoplasmalike organisms by polymerase chain reactions. Biochem. Biophys. Res. Commun. 186:1503-1509.

32. Schneider, B., Seemüller, E., Smart, C. D., and Kirkpatrick, B. C. 1995. Phylogenetic classification of plant pathogenic mycoplasmalike organisms or phytoplasmas. Pages 369-380 in: Molecular and Diagnostic Procedures in Mycoplasmology, Vol. I. R. Razin and J. G. Tully, eds. Academic Press, San Diego.

33. Seemüller, E., Marcone, C., Lauer, U. Ragozzino, A., and Göschl, M. 1998. Current status of molecular classification of the phytoplasmas. J. Plant Pathol. 80:3-26.

34. Uyemoto, J. K., Asai, W. K., and Kirkpatrick, B. C. 1999. Etiology of almond shriveled kernel disease. N.Z. J. Crop Hortic. Sci. 27:225 228.

35. Zhang, Y. P., Uyemoto, J. K., and Kirkpatrick, B. C. 1998. A small scale procedure for extracting nucleic acids from woody plants infected with various phytopathogens for PCR assay. J. Virol. Methods 71:45-50.

36. Zhu, S., Hadidi, A., Lee, I.-M., GundersenRindal, D. E., Zhang, C. 1998. Characterization of the phytoplasmas associated with cherry lethal yellows and jujube witches'broom diseases in China. Acta Hortic. 472:701-714 